\title{
Detection and Identification of Sediment Layer to Discover the Marine Mineral Resources Potential in Aruah Islands
}

\author{
PARENG RENGI ${ }^{1}$, ULIL AMRI $^{2}$, TOMI RAMADONA $^{3}$, EDIAR USMAN $^{4}$, AND BUSTARI ${ }^{1}$ \\ ${ }^{1}$ Department of Water Resources Management, Faculty of Fisheries and Marine Sciences, Riau University \\ ${ }^{2}$ Department of Marine Sciences, Faculty of Fisheries and Marine Sciences, \\ Lambung Mangkurat University, Banjarmasin \\ ${ }^{3}$ Department of Social Economic Fisheries, Faculty of Fisheries and Marine Sciences, Riau University \\ ${ }^{4}$ The National Energy Council, Republic of Indonesia, Jakarta
}

\begin{abstract}
Aruah Islands is located on an international shipping line adjacent to Malaysia. The important aspect in borderline management is the maritime resource potential, one of which is sea minerals. In order to dig the information about marine mineral resources in Aruah Islands, a high-resolution seismic reflection with low frequency was applied, which capable to detect the depth and identify the sedimentary layers clearly and accurately. The depth of water and sediment layers were detected using an echosounder, reason Navi sound type 210 with a tow fish $100 \mathrm{kHz}$ and shallow seismic boomer with a single channel type and wave energy 200 Joules. Gravity core and grab sampler were used to collect the sediment sample. There were three stages on seismic interpretation: sequence analysis, facies analysis, and reflection character identification. Furthermore, sediments containing coarse sand-sized minerals were observed using a microscope. The measurement result of Aruah Islands water depth was ranging from $0-80 \mathrm{~m}$, the deepest part is on the Northern of Batu Mandi island which was $80 \mathrm{~m}$ depth. Seismic profiles indicated that the upper layer of tertiary sedimentary as the youngest rocks. Based on sediment thickness, the thickest area was found on the Western (approx. $50 \mathrm{~m}$ ) and the Northern (approx. $32 \mathrm{~m}$ ). In line with the island's Southern part condition, which was plain or shallow sea exposure, the Southeastern island sediment thickness ranged only about 10$18 \mathrm{~m}$. Generally, based on the analyzed sediment sample, quartz was the main mineral found, which was 60 $80 \%$ of the composition. Other minerals were zircon, tin, hematite, magnetite, limonite, biotite, and dolomite.
\end{abstract}

Keywords: seismic reflection, single channel, mineral sea, Aruah Islands

\section{INTRODUCTION}

Aruah Islands is the outermost region in Rokan Hilir Regency and is located at the North

Correspondence: Pareng Rengi, Department of Water Resources Management, Faculty of Fisheries and Marine Sciences, Riau University. Kampus Bina Widya KM 12.5, Simpang Baru, Kec. Tampan Kota Pekanbaru, Riau (28293). Email : pareng.rengi@ lecturer.unri.ac.id end bordering the waters of North Sumatra Province. Aruah Island cluster has an area of \pm 4 ha, administratively located in the Malacca Strait region, Pulau Jemur Village, Pasir Limau Kapas District, Rokan Hilir Regency, Riau Province. Referring to PP 38/2002 in conjunction with PP $37 / 2008$ regarding the list of geographical coordinates of the baseline points of the Indonesian Islands, it is located approximately

Journal of Wetlands Environmental Management

Vol 9, No 1 (2021) 70 - 80

http://dx.doi.org/10.20527/jwem.v9i1.250 
40 miles or $72.4 \mathrm{~km}$ from Bagansiapi-api and $64.3 \mathrm{~km}$ from Klang Port in Malaysia (Research Center for Fisheries, 2009). An important aspect in the management of border areas is its potential and marine resources. During this time the potential of fisheries has been much noticed and targeted by marine waters.

Some potentials in Rokan Hilir Regency waters as the outermost part are metal and nonmetallic minerals. Mineral metals include tin, ilmenite, hematite, and magnetite, while nonmetallic minerals are in the form of radioactive and quartz. According to Bachelor (1982) the geological waters of the Malacca Strait are included in the western Sumatran granite region as a series of tiny islands stretching from the Thai-Malaysian-Bangka Belitung mainland. This tin path is known as the Tin Belt of Sumatra. Minerals are solid substances (phases) consisting of chemical elements or compounds formed naturally by organic processes, having certain chemical and physical properties, and having the regular placement of atoms inside them or known as crystal structures. In addition, the word mineral also has two other meanings. Firstly, it is organic compounds that are formed in nature that have certain physical and chemical properties, and secondly, it is regular or combined crystalline arrangements that form rocks either in a loose or solid form. Mapping the seafloor in Indonesian waters, especially in the Aruah Islands waters, must continue to be increased for the benefit of the research area. Therefore, it is necessary to investigate both geology and geophysics. The right and fast method for determining water depth, sediment layer and rock layer structure below sea level are hydro-acoustic and gravity core methods. Those are methods capable to reveal the information about basic types of waters using echosounders, also can be applied in water depth mapping or bathymetry. The type of layer, thickness, and sediment deposition environment can be predicted and discovered through the reflection pattern of the acoustic wave. The sediment layer at the bottom of the waters has varied physical properties, one of the physical properties found below the surface is the level of sediment density. This sediment density level is a geological parameter that is very influential on the propagation of acoustic waves. The variation of sediment density on the surface of the sea floor is dominated by loose sediments, consolidated sediments, and compact sediment. Sometimes hard rocks are found, but there is not much variation in an area (Amri, 2016).

According to Rengi and Amri (2016), one of the right methods to tackle this problem is employing the acoustic seismic reflection method. The seismic reflection method is one of the underwater exploration methods based on the measurement of sound wave responses propagating in the water medium and then reflected by objects that hit it during the differences in sediment layers or rock boundaries in the underwater layer. The purpose of this study was to detect depth, find potential information and identify mineral resources in the waters of the Aruah Islands.

\section{MATERIALS AND METHODS}

\section{Time and Location of Research}

The study lasted 15 days, consisting of three stages: recording/sounding depth and sediment 
layer data, collecting sediment sampling, and analyzing data in geophysical and sedimentation laboratories. Bathymetri data, seismic profile data, and sediment samples were carried out in May 2011 in the Aruah Islands water, Rokan Hilir Regency, Riau Province (Figure 1). The megascopic observation and mineral identification were carried out in June 2011 in the Bandung P3GL sedimentation laboratory.

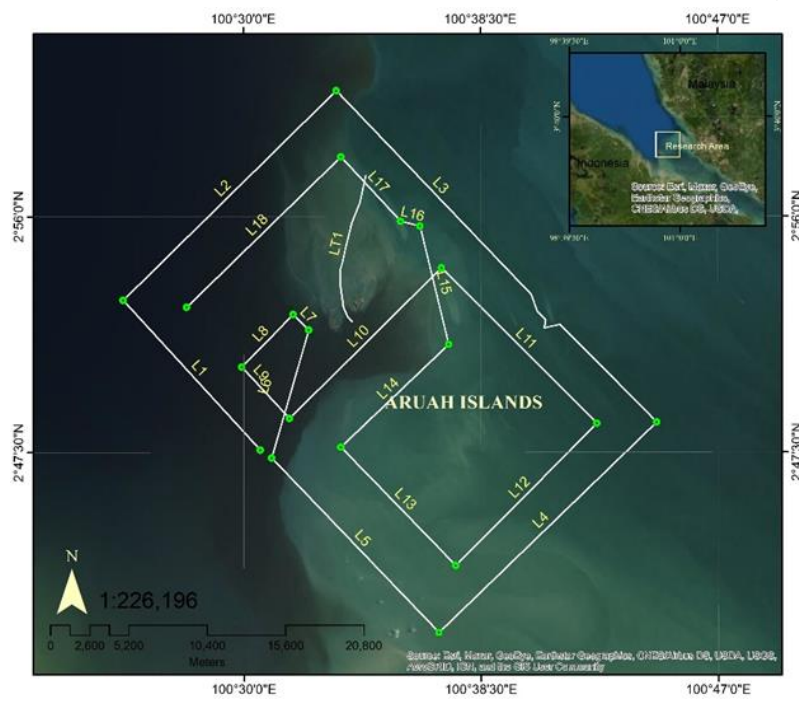

Figure 1. Research Location (Aruah Islands), Seismic Survey and Ship Track (white line), Cross Survey and Sediment Sampling Points (green dots) (modified from Setiady and Usman, 2013).

Seismic trajectories are made parallel and diagonal as additional trajectories that are considered to represent the research area include the outer and inside clusters of the Aruah Islands. The direction of the track starts from the Northwest-Southeast and SouthwestNortheast. Additional trails are carried out between the small islands found in the Aruah Islands. Seismic survey trajectory targets are areas of underwater ancient valleys (paleochannel), underwater valleys (paleo valley), highlands, coral reefs, and basement rocks. These valley areas are metal mineral deposits with heavier density than sediments so that they accumulate to the lowest areas (valleys) to obtain patterns of sediment thickness, ocean depth, and the spread of sediments containing mineral resources. Readings of the position of each seismic track: for the start of the track is Start of Line (SOL) and the end of the track is End of Line (EOL). The relationship between SOL and EOL shows the direction of the path to the wind. In this paper, the discussion is focused on L-T1, L-3, L-8, and L-9 ship trajectory.

\section{Equipment, Acquisition, and Seismic Data Processing}

The equipment used is a reflection seismic type boomer with 200 Joules of wave energy with a penetration depth of more than 100 meters, while energy receivers used are hydrophone multi-element streamer benthos. The determination of ship coordinates uses GPSGARMIN-GPS 75 and GARMIN-GPS 235 connected to an integrated navigation system. The average boat speed is 4 knots 1 hour. The datas were managed automatically and recorded on the data record.

The bathymetry survey (sounding) aims to collect the data of the ocean depth and describe its morphology. The depth data obtained was corrected using tidal data (mean sea level) according to the day during which the recorder is performed. This equipment works as an echosounder sends voice pulses, receives pulses reflected by the seafloor, then displayed on the monitor screen. The equipment works using the principles of propagating sound waves in seawater, where the propagation time of sound waves is then reflected back by the 
sediment/rock layer captured by the transducer and converted into distance/thickness with a set of electronic devices. This tool has a recording capability reaching $\mathrm{t}=250 \mathrm{~ms}$ in Two Way Travel time (TWT) or around 187.5 $\mathrm{m}$ in the water or $200 \mathrm{~m}$ in the sediment.

The sediment sampling was carried out at several points using the gravity core and grab sampler (green dots in Figure 1), after recording bathymetry and seismic data the sediment samples taken were stored and then analyzed in the sedimentation laboratory.

\section{Data Analysis}

The calculation of sediment thickness and bedrock depth based on Equation 1:

$\mathrm{S}=\mathrm{V} \times \mathrm{t}$

where $\mathrm{S}$ is distance, $\mathrm{V}$ is wave velocity in water (V. water) and in sediment (V. sed.) and $\mathrm{t}$ is travel time of sound waves for objects. Wave velocity in water with $\mathrm{V}$. water $=1500$ $\mathrm{ms}$ and waves in sediments with $\mathrm{V}$. sed $=1600$ m sec-1. (Hubrol et al., 1980; Khesin et al., 1995). In this study a sweep of 0.25 seconds and a firing rate of 1 second were used. The total seismic sweep is $250 \mathrm{~ms}$ in Two Way Traveltime (TWT) or $125 \mathrm{~ms}$ in One Way Travel time (OWT). After that, Equation 2 is used to get the actual sediment thickness in the field:

$$
\begin{aligned}
& \mathrm{S}=\mathrm{V} . \mathrm{sed} \times \mathrm{t} \\
& \mathrm{S}=1600 \mathrm{~m} \mathrm{~s}^{-1} \times 125 \mathrm{~ms} \\
& =1600 \mathrm{~m} \mathrm{~s}^{-1} \times 0.125 \text { seconds } \\
& =200 \mathrm{~m} .
\end{aligned}
$$

The width of the paper used was $25 \mathrm{~cm}$, so the total thickness of the paper with the width $25 \mathrm{~cm}$ equals with the size of $200 \mathrm{~m}$ in the field
(1 cm : $8 \mathrm{~m}$ comparison). To find out the depth of water in the seismic paper, Equation 3 is used:

$$
\begin{aligned}
\mathrm{S}= & \text { V.water } \mathrm{x} \mathrm{t} \\
\mathrm{S} & =1500 \mathrm{~m} \mathrm{~s}^{-1} \times 125 \mathrm{~ms} \\
& =1500 \mathrm{~m} \mathrm{~s}^{-1} \times 0.125 \text { seconds } \\
& =187.5 \mathrm{~m} .
\end{aligned}
$$

Thus, the depth of the sea water and the thickness of the sediment as wide as seismic paper is $187.5 \mathrm{~m}$, or equal to the sediment thickness of $200 \mathrm{~m}$.

The analysis of seismic data was carried out in several stages, namely: 1) Analysis of seismic sequences involving the identity of the reflector continuity in each sequence interpreted. 2) Facies analysis, which was the facies difference found in each sequence, allowed the sequence to be divided into several sequences. 3) Analysis of internal reflection character as a basis for interpreting the energy of sedimentation media, sediment types, and depositional environments. In line with Amri (2016), the stages carried out in the interpretation of seismic recordings were as follows: analysis of seismic sequences, facies analysis, analysis of reflector characters, interpretation, and data filtering. Seismic sequence analysis was conducted by dividing the seismic cross-section into several guidelines based on "boundary sequences" in the form of erosion or onlap contacts. In facies analysis, a seismic assembly divider was performed on the seismic cross-section into several sub-sequences based on the reflector image. Analysis of inner reflector characters can be used to interpret sedimentation systems and depositional environments. According to Stephanie et al. (2014) interpretations were made to distinguish the boundary of sedimentary seabed layers, then call the recording data so that it can be 
displayed, and the data can be filtered. Filtering was intended to separate the reflection signal frequency from noise on the recorded data. The subsurface geology was based on the interpretation of reflected seismic data by using seismic stratigraphic principles, which was the introduction of the reflector characteristics of the upper, lower, and inner (internal reflector) of each seismic unit (Sangree and Wiedmier, 1979 and Sherif, 1980).

The results of the interpretation of all seismic records were then divided into seismic sequences. The top sequence was interpreted as the closing sediment or the youngest sediment which was mostly saturated with water. This sequence was characterized by alternating between the dark and transparent reflector and inside there were a parallel reflector and free of the reflector. Characteristics of a reflector-free pattern usually consist of silt and mud which were of Holocene age. In some locations, there were many faults that indicated the possibility of rigid granite metasedimentary rocks. The general characteristics of the reflector were: harmonized $(\mathrm{C}=$ Concordance $)$, parallel lamination $(\mathrm{P}=$ Parallel $)$, letter $\mathrm{S}(\mathrm{S}=$ Sigmoid), oblique (O = Oblique), hilly (MMounded) and avalanche forms (slump). A sediment layer containing metals was interpreted as an area close to the source rock (bedrock), forming a valley as an accumulation of areas of high specific gravity and its lithology was coarse fluvial deposits (coarsegrained fluvial sediments) or called Quaternary sediments (Ringis, 1993)

Core sediment sample treatment was analyzed using Amri's method (2016). Before analyzing the first handling grain size, the cleavage of the parallon pipe core must be considered. The treatment stages were as follows: prepare a core sample to split, mark the tip and the base of the core for symmetrical cleavage. Make sure that the top and bottom do not turn upside down. Cut the core with a splitting knife or core splitting machine. After the cores are split apart, put part A aside to analyze its grain size and part B to be stored.

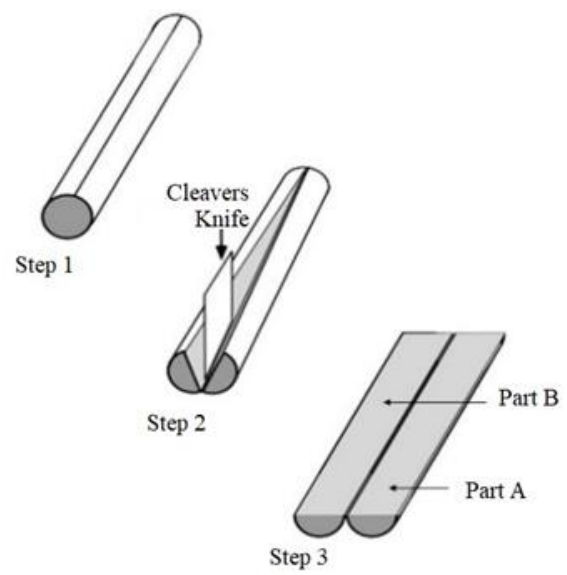

Figure 2. The Step of Core Nucleus Cleavage

Grain size analysis employs a sieve shaker method, while the identification of mineral resources using Shepard method (1954). The analysis of heavy minerals was carried out using a bromoform solution BJ 2.88. Each heavy mineral content $(\%)$ of each location was based on the multiplication of the ratio of the total amount of heavy minerals available to the percent of total heavy minerals.

\section{RESULTS AND DISCUSSION}

\section{The Profile of Depth and Seabed Morphology}

The bathymetry datas were combined with regional secondary data and then corrected by 
bathymetry modeling software so that the morphology obtained was almost the same as the actual condition. The depth of the ocean in the survey area ranged from $0-80 \mathrm{~m}$ from the lowest ebb. The deepest waters in the northern part of Batu Mandi Island were marked with purple contour colors (Figure 3). The bathymetri and the contour of small islands in the Aruah Islands were relative from the Northwest to the Southeast. This pattern was in line with the sedimentation pattern of Quaternary sediments (Holosen-Resen) in seafloor sediments and ocean currents in the survey area with the Northwest-Southeast direction. The Quaternary sedimentary sedimentation pattern with the NorthwestSoutheast direction was characteristic of the Malacca Strait waters (DGOG, 2009). In general, bedrock structure, tectonic development, and Quaternary sedimentation patterns in the study area were relatively parallel according to the pattern of regional tectonic structures (basement depth structure) in the Central Sumatra Basin with the Northwest-Southeast and North-South directions. According to Setiady and Usman (2013), the morphology in the waters of the Aruah Islands was divided into three parts, namely; exposure morphology, undulating valley morphology, and coastal area morphology.

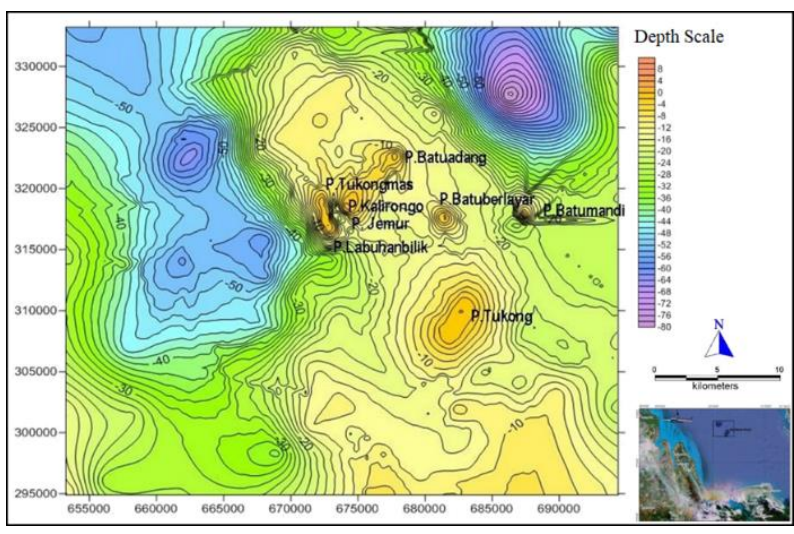

Figure 3. The Map of Aruah Island's Bathymetric

\section{Seismic Profile of Aruah Islands}

L-T1 trajectory. The L-T1 track started from the Northern part of Labuan Bilik Island towards the Northwest of Batu Adang Island. The braking trajectory pattern was curved since it was blocked by several islands, Hence the pattern was adjusted to the bathymetri. Seismic profiles present rock conditions that have been folded. Some locations on seismic profiles did not indicate the existence of a reflector field (strong reflector) because the surface of the seabed was covered by a thick layer of clay or mud so that seismic waves were not reflected strongly.

The L-T1 track showed that Tertiary rocks around Jemur Islands had undergone folding and faulting processes forming a field of corrugated rock and fault fields. This condition was caused by a layer of clay/mud on the thin surface and Tertiary rocks as the bedrock position on the surface so that seismic waves can be reflected clearly (Figure 4). 


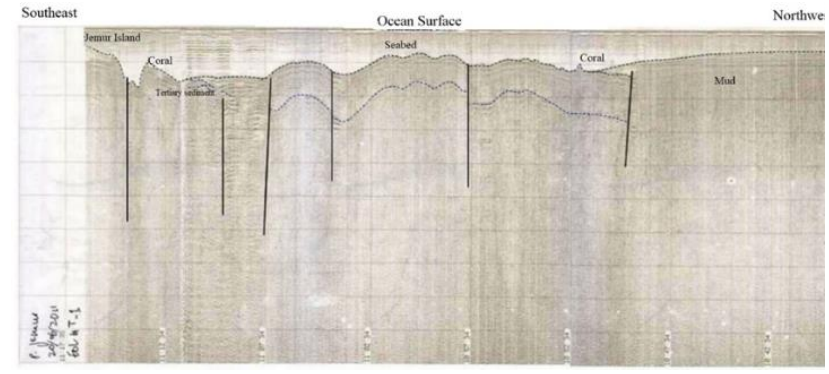

Figure 4. L-T1 Track Seismic Profile

L-3 trajectory. The L-03 seismic track with Southwest-Northeast direction showed the condition of rocks forming a bulge at the surface of the seafloor. The protrusion signifies the raised area of the lining but had not reached the sea surface (Figure 5). At the top of the bulge, there was a coral reef with a reflection pattern in the form of small hills (mounded). The reflector pattern of these small hills was a characteristic of coral reefs. In some places, bulges of coral reefs were embedded in Quaternary rocks down to Tertiary rocks.

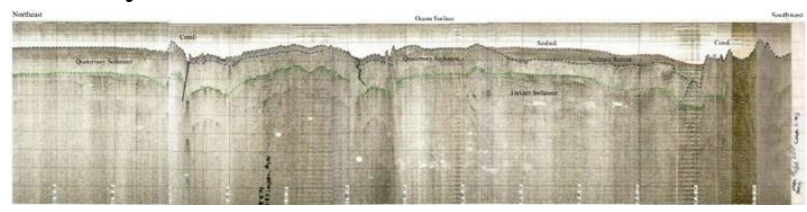

Figure 5. L-3 Track Seismic Profile

L-08 trajectory. Other seismic sections also showed the same sub-surface geological conditions. Seismic tracks L-08 and L-09 show the tertiary sedimentary rocks at the top as the youngest rocks, namely Pleistocene with an absolute age range between 2 - 1.8 million years. The L-08 track shows that the Tertiary sediment layer is slightly tilted (Figure 6), but on the L-09 track (Figure 7) there is still a horizontal layer. That condition indicated that the Tertiary sedimentary layer, as in L-08, has undergone a tectonic process, thus it is seen to cut the field of coating and fault structure at the track.

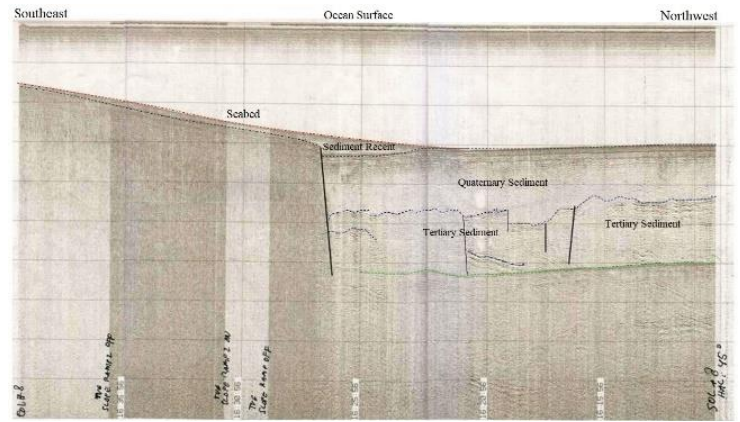

Figure 6. L-8 Track Seismic Profile

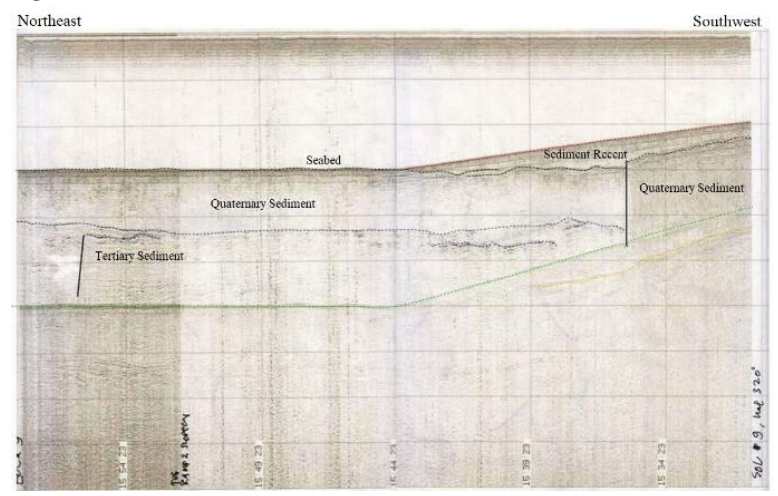

Figure 7. L-9 Track Seismic Profile

\section{Sediment Thickness}

The results of seismic surveys and interpretations of seismic crossings were obtained for Quaternary sediment thickness figures. Quaternary sediment thickness is needed in the development of port infrastructure and mining activities (quartz, tin, and heavy minerals). In this study, it is not recommended to mine mineral resources, if it results in the damage of coral reefs and other biotic environments found in the Aruah Islands region. As for mineral content in seabed sediments, it is an effort towards natural resources inventory in a broad sense as 
a basis for spatial planning and management of natural resource-based marine space. In accordance to Constitution No. 4 of 2009 concerning minerals and coal mining, aside from supporting national development, mineral resources potential is also intended as an effort to regional inventory as well as national mineral reserves.

Based on the Quaternary sediment thickness, the area that has the greatest thickness is in the west reaching $50 \mathrm{~m}$, and the northern part reaching $32 \mathrm{~m}$ (Figure 8). In the

southeast, sediment thickness only ranges from 10-18 $\mathrm{m}$. The thickness of the sediment is in line with the conditions in the southeast which is a plain area or shallow sea exposure.

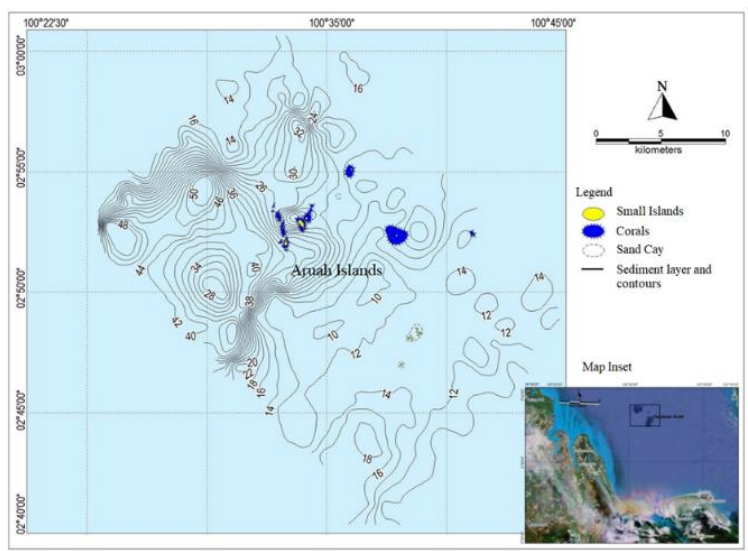

Figure 8. Map of Quaternary Sediment Thickness Distribution in Aruah Islands Waters

\section{Mineral Resources}

Generally, in all samples analyzed, minerals that are commonly found are quartz with a composition between $60-80 \%$. Other minerals are zircon, tin, hematite, magnetite, limonite, biotite, and dolomite. The results of the mineral analysis carried out in the sedimentology and
P3GL mineral laboratory were the same as those found by Setiady and Usman (2013), namely quartz, magnetite, cassiterite/tin, zircon, hematite, limonite, biotite, and dolomite.

Quartz is one of the minerals found on the top layer of the earth/crust. This type of stone is formed of silicon and dioxide. This mineral has a hexagonal crystal structure, formed at all mineral formation temperatures. Quartz is very resistant to mechanical and chemical weathering, usually used as airing gem, filter making materials, frequency control, timers, electronic circuits, and various other special devices. Quartz is composed of $\mathrm{SiO}_{2}$, usually brown, black, or purple, rarely found in green and other colors depending on the mixture contained in it. In the Mohr's scale, quartz has a hardness of 7, translucent. Quartz is classified as a silicate mineral, characterized by a bond between the $\mathrm{Si}$ and $\mathrm{O}$ elements. A silicate is a molecular group containing $\mathrm{SiO}_{4}$ tetrahedral. This group of minerals covers $25 \%$ of all known minerals and $40 \%$ of minerals commonly found in rocks. The mineral content of quartz in the study area is dominantly found in silt sand and clay-sand sediments with a depth of seabed between 11-55 meters.

Zircon $\left(\mathrm{ZrSiO}_{4}\right)$ is formed as mineral accessories in rocks containing Na-feldspar (acid igneous rocks and metamorphic rocks). Zircon contains the element of iron, calcium sodium, manganese, and other elements that cause zircon colors to vary from clear white to yellow, greenish, reddish-brown, brownish-yellow, and dark. Stones belonging to zircon will change color if heated. This mineral is used as a raw material for electronic components, such as ceramic coating materials, catalysts, gems, and others. Colors range from clear white to yellow, 
greenish, reddish-brown, brownish-yellow, and dark. Crystal systems include monoclinic, prismatic, pyramidal, and tetragonal, the luster of wax to metal. It has a perfect-irregular cleavage; hardness 6.5-7.5 specific gravity 4.5 5.8, refraction index 1.92-2.19, missing incandescent $0.1 \%$, and melting point $2500{ }^{\circ} \mathrm{C}$ (Puslitbang Tekmira, 2005). Examples containing zircon beads indicate the presence of purplish color emission (Figure 10). The color emission generally shows the content of radioactive elements, zircon beads emit purple light with a sharp enough intensity.

The lead is a silvery-white metal, with low hardness counted as much as $7.3 \mathrm{~g} / \mathrm{cm} 3$ density, has high thermal and electrical conductivity. Under normal conditions $\left(13-160^{\circ} \mathrm{C}\right)$ this metal is shiny and easily formed. Tin is formed as primary deposits in granite rocks and in the area reached by metamorphic sedimentary rocks which are usually associated with tourmaline and tin quartz veins as well as secondary deposits containing alluvium, alluvial, and colluvium deposits. Minerals contained in tin ore are generally the main minerals, namely cassiterite, usually used as a raw material for coating metal, solder, souvenirs, and others.

Hematite is a form of iron (III) oxide $\left(\mathrm{Fe}_{2} \mathrm{O}_{3}\right)$ mineral. Hematite crystallizes in the rhombohedral system and has the same crystal structure as ilmenite and corundum. Hematite and ilmenite form a solid solution at $950^{\circ} \mathrm{C}$. Hematite is a mineral that is black to silvergray, brown to brownish-red with a roughness scale of 5-6. According to Setiady and Usman (2013), hematite's included the oxide group, brownish-black, rounded shape, submetallic luster, hardness 5.5-6. Specific gravity 5-5.2.
This mineral was found in all sediment samples.

Magnesite/magnesium is the lightest metal with a specific gravity of 1.74, considerably strong and in alloy form, resistant to corrosion in the air but not resistant to seawater and flammable. Magnesite can be found in secondary minerals and is usually associated with sedimentary rocks or metamorphic rocks, derived from marine deposits. Magnesite is generally rarely found in mineral form but in its entirety is found in siderite solid solutions $\left(\mathrm{FeCO}_{3}\right)$ together with $\mathrm{Mn}$ and $\mathrm{Ca}$ which can replace the $\mathrm{Mg}$ element. Magnesite is often used for refractory materials, sorel cement industry, insulation materials, agriculture, livestock, rubber industry, and others.

Limonite was found only in one sediment sample, which was very small at the KA09 point. Limonite, sometimes is also called low-grade nickel ore, is an iron ore consisting of a mixture of hydrated iron (III) oxides in various compositions. Its chemical formula is $\mathrm{FeO}(\mathrm{OH}) \cdot n \mathrm{H}_{2} \mathrm{O}$. Its color varies from bright lemon yellow to grayish gray opaque. The level of its roughness ranges from 4-5.5 (MacEachern, 1996). One of the uses of limonite is as a color pigment (Heckel, 1910).

Biotite is a common philosophical mineral present in the mica group. Its chemical formula is $\mathrm{K}\left(\mathrm{Mg}, \mathrm{Fe}^{2+}\right)_{3}\left(\mathrm{Al}, \mathrm{Fe}^{3+}\right) \mathrm{Si}_{3} \mathrm{O}^{10}(\mathrm{OH}, \mathrm{F})_{2}$. Formed at a temperature of $700^{\circ}-800^{\circ} \mathrm{Cdue}$ to the process of magmatism, metamorphism, and hydrothermal processes. The cooling of magma in the form of silicate melt is followed by a crystallization process that can take place under or above the earth's surface through volcanic eruptions. The group of igneous rocks which contain biotite, if later exposed on the surface, will come into contact with the atmosphere and hydrosphere 
which causes the weathering process. This mineral has a dark green, dark brown, blackishbrown color. The hardness level is 2.5 , specific gravity 2.9-3.4. This mineral is usually used as plaster material.

Dolomite including carbonate mineral clusters, pure dolomite minerals theoretically contain $45.6 \% \mathrm{MgCO}_{3}$ or $21.9 \% \mathrm{MgO}$ and $54.3 \% \mathrm{CaCO}_{3}$ or $30.4 \mathrm{CaO}$. The chemical formula for mineral dolomite is written $\mathrm{CaCO}_{3} \cdot \mathrm{MgCO}_{3}, \mathrm{CaMg}\left(\mathrm{CO}_{3}\right)^{2}$, or CaxMg1$\mathrm{xCO}_{3}$ with a smaller $\mathrm{x}$ value of one. Dolomite is rarely pure, generally, these minerals are always present together with limestone, quartz, pyrite, and clay. In dolomite minerals, there are also impurities, especially iron ions. Dolomite is grayish-white or bluish with softer hardness than limestone ranging from 3.5-4.0, which is hard-pressed between 2.8-2.9, fine-grained to rough, and has an easy to absorb water, and is easily destroyed. The use of dolomite in the industry is not as wide as the use of limestone and magnesite, usually used in industrial fields (Puslitbang Tekmira, 2005).

Not all examples of sediments in the sea are mineral grains, but there are also clay minerals and shell fragments. Clay and shell minerals are separated from sand samples because they are not economical minerals, thus their species are not identified under a microscope. Generally, mineral grains still show angles forming sub-angular granules. Granules closed to the corner show conditions not far from the source. This condition also reinforces the notion that quartz granules do not originate directly from granite rocks. In the coastal area, almost all the sediments on the beach form a stretch of white sand. The results of observations on microscopes depict that the largest granules are quartz and other heavy minerals. The presence of quartz granules originated from sandstone units in tertiary sediments which are contained in small islands in the Aruah Islands. Another example (Figure 10) shows the presence of heavy minerals such as magnetite, hematite, and black ilmenite. The black grain is dominantly found in the coastal waters of the study area. Figure 9. Some types of minerals (magnetite (a), hematite (b), dolomite (c), and zircon (d)) were found at the study site.

\section{CONCLUSIONS}

In general, bedrock structure, tectonic development, and Quaternary sedimentation patterns in the study area are relatively parallel in accordance with the pattern of regional tectonic structures (basement depth structure) in the Central Sumatra Basin with the northwestsoutheast and north-south direction. The mineral content in seafloor sediments in an effort to inventory natural resources in a broad sense as a basis for spatial planning and management of natural resource-based marine space. Based on the Quaternary sediment thickness, the area that has the largest thickness is in the west reaches 50 $\mathrm{m}$ and the northern reaches $32 \mathrm{~m}$. The presence of quartz granules originates from a group of sandstone units in tertiary sediments that comprise small islands in the Aruah Islands. Generally, mineral grains still show angles forming sub-angular granules. Granules closed to the corners show conditions not far from the source. This condition also reinforces the notion that quartz granules do not originate directly from granite rocks. 


\section{REFERENCES}

Amri, U. 2016. Integrasi Data Sub-Bottom Profile dan Gravity Core Untuk Menentukan Dinamika Sedimentasi Resen di Perairan Utara Wokam (Thesis). Bogor. Institut Pertanian Bogor. 91 hal.

Anthony, J. W., Bideaux, R. A., Bladh, K. W., Nichols, M. C. (ed.). 2005. Hematite.Handbook of Mineralogy.III (Halides, Hydroxides, Oxides). Chantilly. VA, US. Mineralogical Society of America.ISBN0962209724. Diakses tanggal 25 November 2016.

Directorate General of Oil and Gas. 2009. Indonesia: Petroleum Bidding Round 2009. Directorate General of Oil and Gas, Department of Energy and Mineral Resources, Jakarta: 89pp.

Pusat Penelitian dan Pengembangan

Perikanan. 2009. Pedoman Teknis Pengelolaan Terumbu Buatan. Dirjen Perikanan, BPPP. Dept. Pertanian.

Rengi, P. dan Amri, U. 2016. Pemetaan Energi Biogenik pada Formasi Alluvial di Pulau Topang dan Perairan Utara Pulau Merbau Menggunakan Sistem Akustik Seismik Dangkal. Prosiding Seminar Nasional Lahan Basah Universitas Lambung Mangkurat 2016. Banjarmasin.

Setiady, D. dan Usman, E., 2013. Hubungan Kandungan Mineral Kuarsa dan Mineral Lainnya Dengan Sedimen Dasar laut di Kepulauan Aruah Provinsi Riau. Buletin Sumberdaya Geologi. Vol. 8, No. 2. (8799). Bandung.

Stephanie, Widada S, Rahardiawan R. 2014. Interpretasi lapisan sedimen dasar laut di perairan Utara Jawa (lembar peta 1310) menggunakan sub-bottom profile. J. Oseanografi. 3(4):504-510. 